\title{
Rapeseed meal as a protein source for high-production dairy cows on grass silage- and hay-based feeding
}

\author{
LIISA SYRJÄLÄ-QVIST, MIKKO TUORI and JOUKO SETÄLÄ \\ Department of Animal Husbandry \\ University of Helsinki, 00710 Helsinki 71
}

\begin{abstract}
Twenty-four dairy cows were used in an experiment in which 1) soybean meal, 2) rapeseed meal and 3) rapeseed meal plus urea were compared for feeding value, when given as protein sources in grass silage- and hay-based feeding. About $25 \%$ of the digestible crude protein required for milk production was replaced with these protein sources. The rapeseed meal was mainly of the Span variety. The rapeseed meal composed $13 \%$ of a concentrate mixture also containing barley, oats and molassed beet pulp. The daily consumption of rapeseed meal was up to $1.2 \mathrm{~kg} / \mathrm{cow}$, the average being $1.0 \mathrm{~kg} / \mathrm{cow}$. As a protein source the rapeseed meal was almost equivalent to the soybean meal. There were no significant differences between the groups in the intake or utilization of the feeds, milk production or milk composition, or liveweight changes. The replacement of silage protein with rapeseed meal or with soybean meal improved the utilization of the protein of the whole ration for milk production.
\end{abstract}

\section{Introduction}

Rapes are becoming an important source of protein in countries like Finland where the conditions limit the cultivation of other plant usable as protein concentrates. While the plant breeders in many countries are developing new varieties with a low content of antinutritional substances, i.e. low levels of glucosinolates in the meal, the plant breeders in Finland are working to produce varietes that will grow in our conditions as well. Nowadays the rapeseeds processed for animals in Finland are of domestic origin. Although the commercial product is a mixture of extracted meals of different varietes, analysis of its glucosinolate content gives a fairly accurate estimate of its quality.

When the rapeseed varieties used had a high glucosinolate content, it was generally recommended that the level of rapeseed meal in concentrate mixtures fed to lactating cows should not be increased above $10 \%$ (WALDERN 1973, LAARVELD and CHRISTENSEN 1976, LINDELL and KNUTSSON 1976). Higher levels of this kind of rapeseed meal could cause palatability problems, decreased milk yields, changes in the milk composition, hypothy- 
rodism or fertility disorders. The 1970s saw the introduction of the so-called double zero varieties, where the glucosinolate content of the rapeseed meal was under $1 \%$. This low-glucosinolate rapeseed meal has been used at a level of over $20 \%$ in the concentrate mixture without adverse effects of performance at least in short-term use (INGALLS and SHARMA 1975, FISHER and WALSH 1976, SHARMA et al. 1977, PAPAS et al. 1978, 1979). Since the rape varieties with a high glucosinolate content have so far been easier to cultivate and give better seed yields in Finnish conditions than those with low glucosinolates (ANON. 1980a), we need more information on the use of rapeseed varieties with a fairly high glucosinolate content at levels above 10 $\%$ of the concentrate. The main purpose of this investigation was to study the value of rapeseed meal used alone or together with urea to replace soybean meal as a protein source for high-production cows on silage- and hay-based feeding. The rapeseed meal used was mainly the Span variety, which belongs to the high-glucosinolate category.

\section{Experimental procedures}

The experiment was performed with 24 Ayshire cows. At the beginning of the experiment the average time that had elapsed from calving was 45 days. The experiment lasted 16 weeks. During the standardization period of 2 weeks, all the animals received the same feeding, consisting of hay, grass silage and grain concentrates, adjusted to their nutrient requirements (BREIREM 1969). At the end of this period the cows were divided into three groups that were as similar as possible in respect to their fat-corrected milk

Table 1. The mean chemical composition and feeding value of the feeds ${ }^{1)}$.

\begin{tabular}{lcrrrrrrr}
\hline & Hay & $\begin{array}{c}\text { Grass } \\
\text { silage }{ }^{2)}\end{array}$ & Barley & Oats & $\begin{array}{c}\text { Molassed } \\
\text { beat pulp }\end{array}$ & $\begin{array}{c}\text { Molassed } \\
\text { beat pulp } \\
\text { with urea }\end{array}$ & $\begin{array}{c}\text { Rapeseed } \\
\text { meal }\end{array}$ & $\begin{array}{c}\text { Soybean } \\
\text { meal }\end{array}$ \\
\hline Dry matter, \% & 85.4 & 24.5 & 75.2 & 73.7 & 88.2 & 90.1 & 89.7 & 88.1 \\
\% of DM & & & & & & & & \\
Ash & 5.5 & 9.2 & 2.9 & 3.3 & 8.9 & 7.5 & 7.6 & 6.0 \\
Crude protein & 8.9 & 15.1 & 13.5 & 13.8 & 13.4 & 25.8 & 38.4 & 52.3 \\
Crude fat & 2.0 & 5.3 & 2.3 & 4.8 & 2.8 & 3.1 & 3.7 & 1.3 \\
Grude fibre & 35.5 & 32.6 & 6.1 & 10.4 & 17.9 & 15.4 & 13.7 & 6.8 \\
N-free extract & 48.1 & 37.8 & 75.3 & 61.7 & 57.0 & 48.2 & 37.1 & 32.2 \\
kg DM/f.u. & 1.8 & 1.5 & 0.9 & 1.1 & 1.1 & 1.1 & 1.1 & 0.9 \\
g DCP/f.u. & 81 & 152 & 88 & 105 & 79 & 158 & 350 & 431 \\
\hline
\end{tabular}

$\mathrm{DM}=$ Dry matter

DCP $=$ digestible crude protein

f.u. $=$ feed unit $=0.7$ Starch equivalent

1) The feeding values were calculated using the digestibility coefficients and values presented by ANON. (1969) and NEHRING (1970).

2) $\mathrm{pH}$ of silage 4.17 , sugars $2.44 \%$, lactic acid $7.90 \%$, acetic acid $2.63 \%$, propionic acid $0.20 \%$, butyric acid $0.11 \%, \mathrm{NH}_{3}-\mathrm{N} 0.19 \%$ and water solube $\mathrm{N} 1.37 \%$ of DM. 
Table 2. The percentages of different feeds in the concentrate mixture.

\begin{tabular}{lccc}
\hline & Soybean & $\begin{array}{c}\text { Groups } \\
\text { Rapeseed }\end{array}$ & $\begin{array}{c}\text { Rapeseed- } \\
\text { urea }\end{array}$ \\
\hline Barley & 49 & 45 & 48 \\
Oats & 24 & 23 & 24 \\
Molassed beet pulp & 16 & 16 & 2 \\
Molassed beet pulp with urea & - & - & 16 \\
Rapeseed meal & - & 13 & 7 \\
Soybean meal & 8 & - & - \\
Minerals & 3 & 3 & 1.22 \\
kg/f.u. & 1.20 & 1.22 & 123 \\
DCP, g/f.u. & 123 & 125 & \\
\hline
\end{tabular}

(FCM) yields, days after calving and liveweights. During the following 2 weeks the animals were changed to the experimental feeds.

During the test period, which lasted 12 weeks, the basic feeds were hay, grass silage, molassed beet pulp and barley and oats preserved with propionic acid (Table 1) plus minerals and vitamins. The rations for all the groups were made up from these basic feeds according to their nutrient requirements, except that of protein. In the different groups $25 \%$ of the digestible crude protein (DCP) required for milk production was given as:

1) Soybean meal

2) Rapeseed meal

3) Rapeseed meal and urea

The amount of energy which the animals received in these protein feed was taken into account by making a corresponding reduction in the energy supply of the feeds. The protein feeds were mixed with the other concentrates (Table 2).

The rapeseed meal was mainly of the Span variety. The glucosinolate content was $0.9 \%$ of dry matter (HILTUNEN 1980) and the tannin content $1.4 \%$ (ANON. 1970). The urea content of the molassed beet pul was $4 \%$.

The feeding procedures, sampling, analyses, calculations and statistical treatments were as described by SYRJÄLÄ et al. (1978).

\section{Results and discussion}

\section{Palatability of feeds and nutrient supply}

The average intake of the feeds during the test period was equal in the different groups (Table 3, Fig. 1). In all the groups the total energy and protein received by the cows in their rations were about $9 \%$ lower than the corresponding feeding standards for maintenance and milk production. The palatability of the concentrate mixture was, however, good in all the groups. In the case of the hay and the silage, especially the latter, consumption problems occurred from time to time; the quality of the silage changed 

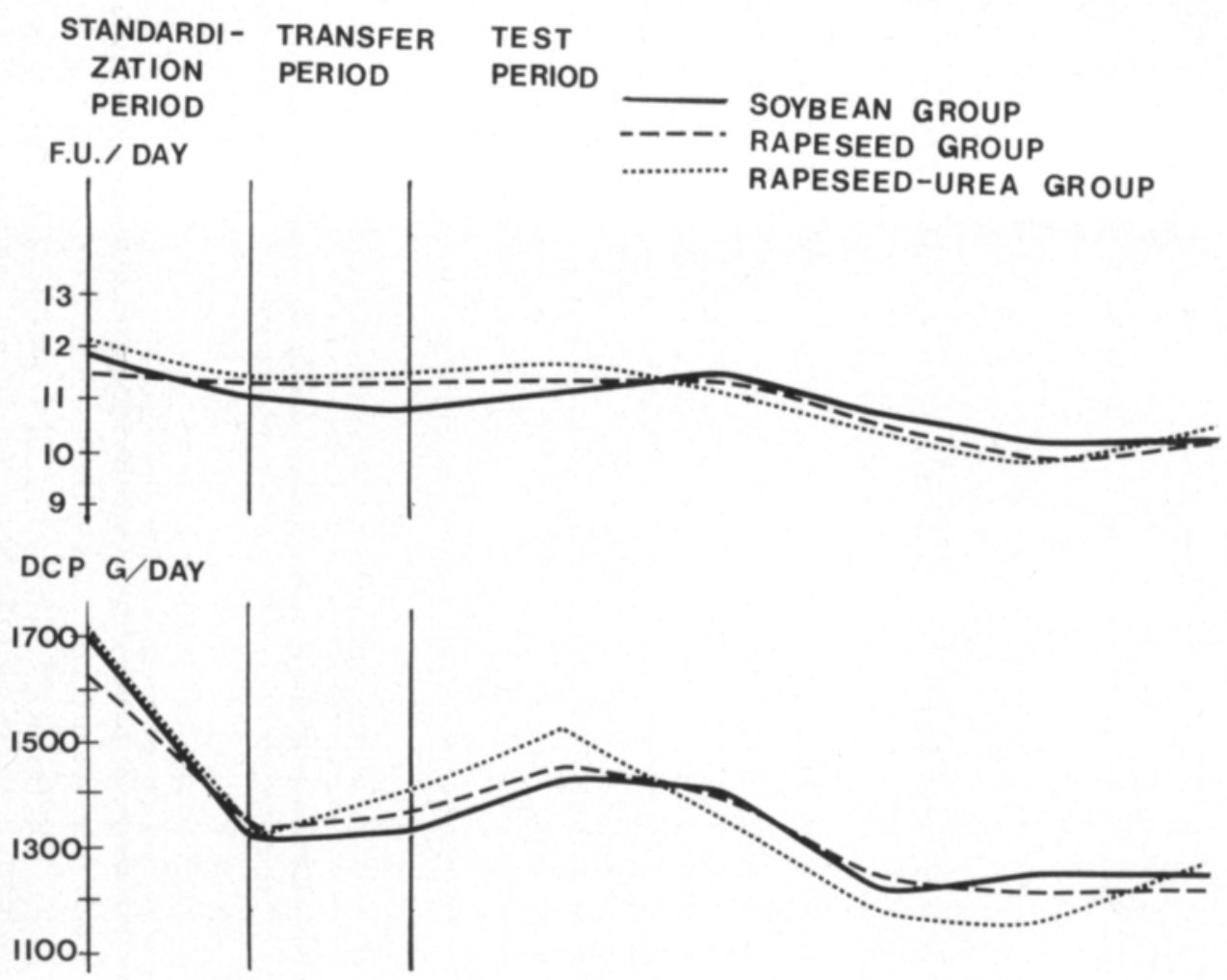

DM KG/DAY

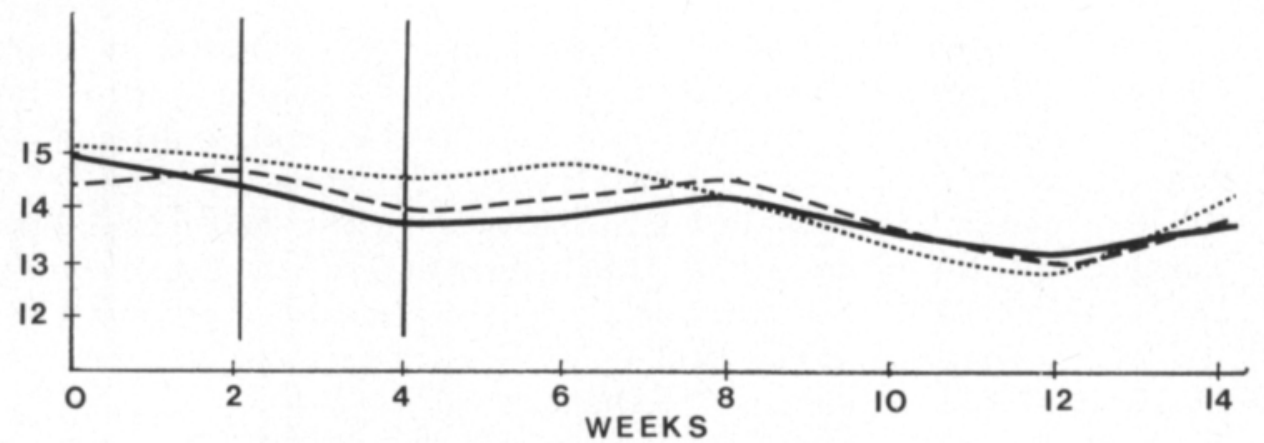

Fig. 1. The average intake of energy, protein and dry matter in the different groups.

during the experiments. These problems were the main reason for the energy and protein deficiency.

The average daily consumption of rapeseed meal in the rapeseed groups was $1.0 \mathrm{~kg}(1.2-0.9 \mathrm{~kg})$ and in the rapeseed-urea group $0.6 \mathrm{~kg}(1.0-0.5 \mathrm{~kg})$. The average daily urea intake in the latter group was $61 \mathrm{~g}$. In the soybean group the average daily soybean meal consumption was $0.6-0.7 \mathrm{~kg}$.

The results in the literature regarding the effect of rapeseed meal on the feed consumption have varied somewhat. The main reasons have been variation in the amounts and proportions of rapeseed meal in the concentrate mixture, and variation in the stage of lactation of the cows. 
Table 3. The mean intake and yields in the different groups.

\begin{tabular}{|c|c|c|c|c|c|c|}
\hline & \multicolumn{3}{|c|}{ Standardization period } & \multicolumn{3}{|c|}{ Test period } \\
\hline & \multicolumn{3}{|c|}{ Groups } & \multicolumn{3}{|c|}{ Groups } \\
\hline & $\begin{array}{l}\text { Soy- } \\
\text { bean }\end{array}$ & $\begin{array}{c}\text { Rape- } F \\
\text { seed }\end{array}$ & $\begin{array}{l}\text { Rapeseed- } \\
\text { urea }\end{array}$ & $\begin{array}{l}\text { Soy- } \\
\text { bean }\end{array}$ & $\begin{array}{r}\text { Rape- } \\
\text { seed }\end{array}$ & $\begin{array}{r}\text { Rapeseed- } \\
\text { urea }\end{array}$ \\
\hline DM intake, $\mathrm{kg} / \mathrm{d}$ & 14.9 & 14.4 & 15.1 & 13.6 & 13.8 & 13.9 \\
\hline Hay & 2.1 & 2.0 & 2.0 & 3.7 & 3.6 & 3.7 \\
\hline Silage & 6.6 & 6.4 & 6.9 & 3.4 & 3.9 & 3.7 \\
\hline Concentrates & 6.2 & 6.0 & 6.2 & 6.5 & 6.3 & 6.5 \\
\hline Soybean meal & & & & 0.5 & - & - \\
\hline Rapeseed meal & & & & - & 0.8 & 0.4 \\
\hline \multicolumn{7}{|l|}{ Energy intake } \\
\hline $\mathrm{ME}, \mathrm{MJ} / \mathrm{d}$ & 155 & 150 & 157 & 145 & 146 & 148 \\
\hline f.u./d & 11.8 & 11.4 & 12.0 & 11.1 & 11.1 & 11.2 \\
\hline DCP intake, $\mathrm{g} / \mathrm{d}$ & 1702 & 1638 & 1734 & 1336 & 1355 & 1377 \\
\hline Urea intake, $\mathrm{g} / \mathrm{d}$ & - & - & - & - & - & 61 \\
\hline Liveweight, kg & 526 & 524 & 508 & 518 & 522 & 498 \\
\hline Liveweight change, $\mathrm{kg} / \mathrm{d}$ & -0.42 & -0.22 & -0.58 & +0.13 & +0.15 & +0.11 \\
\hline $\mathrm{FCM}, \mathrm{kg} / \mathrm{d}$ & 20.7 & 22.0 & 22.5 & 19.1 & 19.0 & 19.7 \\
\hline Milk fat $\%$ & 4.63 & 4.59 & 4.79 & 4.48 & 4.36 & 4.73 \\
\hline -"-protein $\%$ & 3.32 & 3.29 & 3.41 & 3.32 & 3.39 & 3.46 \\
\hline \multicolumn{7}{|l|}{ Feed utilization } \\
\hline Production f.u./kg FCM & 0.41 & 0.35 & 0.41 & 0.35 & 0.35 & 0.36 \\
\hline Production DCP, g/kg FCM & & & & 54 & 55 & 55 \\
\hline
\end{tabular}

\section{Production and feed utilization}

The milk production and the fat and protein content of the milk remained at the same level in the different groups (Table 3, Fig. 2) and no statistically significant differences existed during the test periot $(\mathrm{P}>0.05)$. The average decrease in the milk yield from the standardization period to the test period in the soybean group was $1.6 \mathrm{~kg}$, in the rapeseed group $3.0 \mathrm{~kg}$ and in the rapeseed-urea group $2.8 \mathrm{~kg} \mathrm{FCM} /$ day.

The milk fat content also diminished from the standardization period to the test period, the average decrease in the different groups being $0.13,0.24$ and $0.01 \%$ units, respectively. The milk protein content increased slightly, on average by $0.02,0.11$ and $0.11 \%$ units. The changes in the composition of the diet, especially the concentrate/forage ratio, may have contributed to these changes in the milk composition, although the ratio remained within the optimal limits (MCCULLOUGH 1974). Calculated from the dry matter of the diet, the concentrate/forage ratio in the different groups in the standardization period averaged 39/61 and in the test period 46/54.

The consumption of feed units and digestible crude protein per $\mathrm{kg}$ fatcorrected milk was used as a measure of feed utilization (Table 3). The f.u. and DCP needed for maintenance were substracted from the total supply, those values being $4 \mathrm{f}$.u. per $500 \mathrm{~kg}$ liveweight and $75 \mathrm{~g} \mathrm{DCP} /$ maintenance f.u. (BREIREM 1969). The energy required for a change in liveweight was 

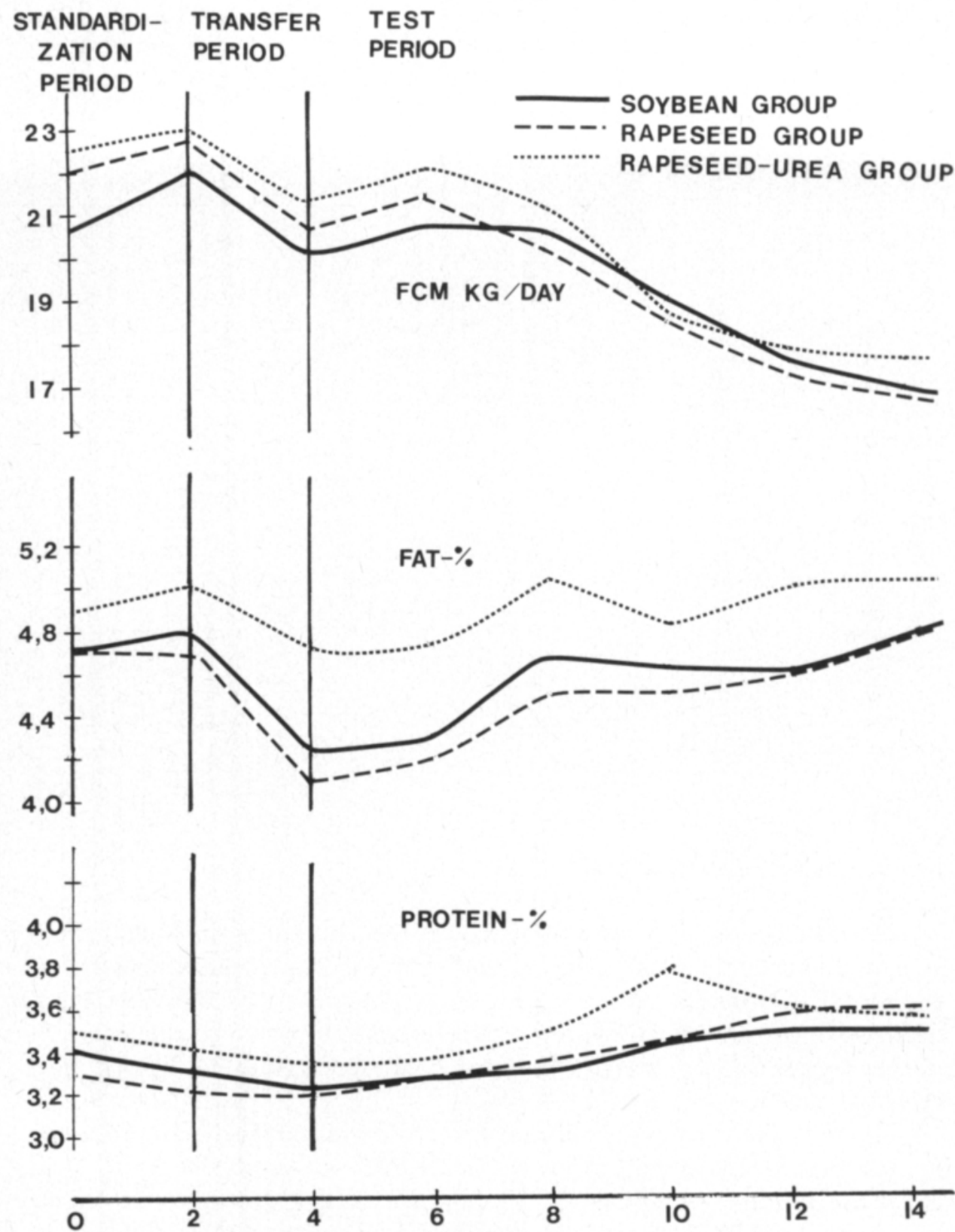

Fig. 2. Milk yield and composition in the different groups.

taken as $2 \mathrm{f}$.u. $/ \mathrm{kg}$ change. No corrections were used for the DCP calculations.

There were no significant differences between the groups in feed utilization. In the test period fewer production f.u's were needed per kg FCM than in the standardization period. This is partly caused by the increased proportion of hay in the test period. The f.u. measures net energy in fattening, and it underestimates the net energy value of hay in lactation. 
In the standardization period the amount of silage fed per cow and day averaged $30 \mathrm{~kg}$ and that of hay $2.3 \mathrm{~kg}$. In the test period the silage amount was decreased to $16-17 \mathrm{~kg} /$ day and the hay amount increased to $4.2 \mathrm{~kg} / \mathrm{day}$, in order to decrease the protein content of the basic feeds and leave room for the experimental protein concentrates. The crude protein in silage is in a more soluble form and it is also degraded more rapidly in the rumen than that of hay, soybean meal and rape seed meal (SYRJÄLÄ 1977, SETÄLÄ and SYRJÄLÄ-QVIST 1982 a). The fact that the high-production cow also needs a certain amount of protein whose rumen degradability is low (ANON. 1980 b), may also explain why replacement of silage protein with hay and soybean or rapeseed protein in this experiment improved protein utilization.

It should be mentioned here that both the variety of the seed and the processing technique used in the extraction of the oil have a certain effect on the rumen degradability of rapeseed meal (SETÄLÄ and SYRJÄLÄ-QVIST 1982 b) and thus also affect protein utilization. The processing technique needs, however, further investigation.

\section{Composition of blood and health of the animals}

There were no significant differences between the groups in the concentrations of the blood constituents determined (Table 4). All the values fall within the normal ranges (RAUEN 1964, HEWETT 1974). Only urea-N, especially in the animals on the rapeseed-urea diet, was higher than in some other experiments (LAARVELD and CHRISTENSEN 1976).

The health of the animals was good during the experiment. Like most of the other studies, however, except those of LINDELL (1976), this experiment lasted too short a time and comprised too small a material to allow any definite conclusions. In future investigations, special attention should be paid to the health and fertility of cows receiving rapeseed meal.

Acknowledgements. - We wish to express our best thanks to Mrs. Hanna Korpijaakko and Mrs. Alem Tsehai Tesfa for technical assistance throughout the experiment.

Table 4. Haematological criteria and chemical constituents of the blood of the cows in the test period.

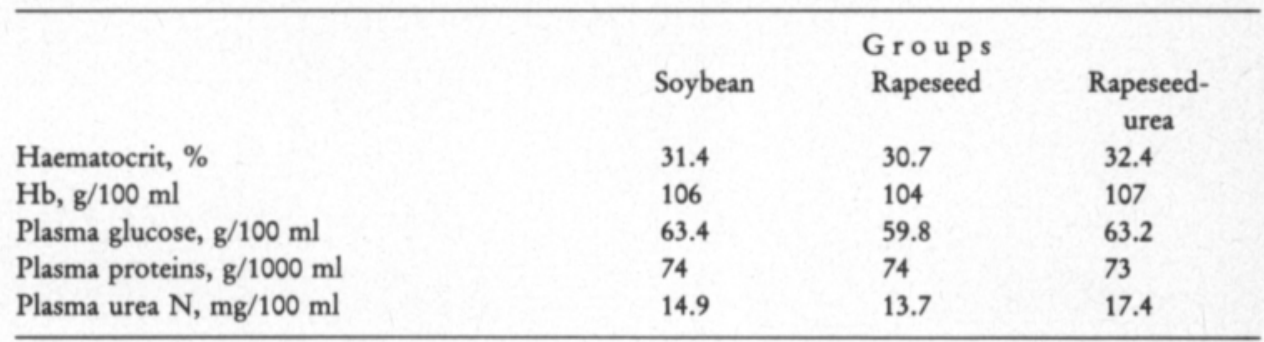




\section{References}

ANON. 1969. N. J. F. Fodermitteltabel. 49 p. Gjøvik.

ANON. 1970. A.O.A.C. Official methods of analysis of the Association of Official Analytical Chemistry. 11 th ed. 125 p. Wisconsin.

ANON. 1980 a. Hankkijan koetuloksia.

ANON. 1980 b ARC. The nutrient requirements of ruminant livestock. C.A.B. 351 p.

BREIREM, K. 1969. Fôrnormer K. K. Heje/Singsaas Lommealmanakk 1: 120. Oslo.

FISHER, L. J. \& WALSH, D. S. 1976. Substitution of rapeseed meal for soybean meal as a source of protein for lactating cows. Can. J. Anim. Sci. 56: 233-242.

HEWETT, C. 1974. On the causes and effects of variations in the blood profile of Swedish dairy cattle. Acta Vet. Scand., Suppl. 50, 152 p.

HILTUNEN, R. 1980. Determination of glucosinolates from Brassica Sp. by glass capillary gas chromatography. Acta Farm. Fenn. 89: 31-36.

INGALLS, J. R. \& SHARMA, H. R. 1975. A nutritional comparison of various rapeseed and mustard seed solvent - extracted meals. Can. J. Anim. Sci. 55: 721-729.

LAARVELD, B. \& CHRISTENSEN, A. 1976. Rapeseed meal in complete feeds for dairy cows. J. Dairy Sci. 59: 1929-1935.

LINDELL, L. 1976. Rapeseed meal in rations for dairy cows. 2. Comparison of two levels of rapeseed meal. Swedish J. Agric. Res. 6: 65-71.

LINDELL, L. \& KNUTSSON, P-G. 1976. Rapeseed meal in rations for dairy cows. 1. Comparison of three levels of rapeseed meal. Swedish J. Agric. Res. 6: 55-63.

MCCULLOUG, M. E. 1974. Optimum rations for feeding dairy cows, theory and practice. World Rev. Anim. Prod. 3: 84-90.

NEHRING, K., BEYER, M. \& HOFFMANN, B. 1970. Futtermitteltabellenwerk. 460 p. Berlin.

PAPAS, A., INGALLS, J. R. \& CAMPBELL 1979. Studies on the effects of rapeseed meal on the thyroid status of cattle, glucosinolate and iodine content of milk and other parameters. J. Nutr. 109: $1129-1139$.

PAPAS, A., INGALLS, J. R. and CANSFIELD, P. 1978. Effects of Tower and 1821 rapeseed meals and Tower gums on milk yield, milk composition and blood parameters of lactating dairy cows. Can. J. Anim. Sci. 58: 671-679.

RAUEN, H. M. 1964. Biochemisches Taschenbuch II. 1084 p. Berlin.

SHARMA, H. R., INGALLS, J. R. and MCKIRDY, J. A. 1977. Effects of feeding a high level of Tower rapeseed meal in dairy rations on feed intake and milk production. Can. J. Anim. Sci. 57: 653-662.

SETÄLÄ, J. \& SYRJÄLÄ-QVIST, L. 1982 a. (Unpublished).)

SETÄLÄ, J. \& SYRJÄLÄ-QVIST, L. 1982 b. Ruminal protein degradation of processed rapeseed. EAAP Congress, Leningrad.

SYRJÄLÄ, L. 1977. Effect of fermentation level on the utilization of silage protein. Proc. XIII Int. Grassland congress, Leipzig, DDR, Eds. Wojan, E. \& Thons, H. p. 1465-1468.

SYRJÄLÄ, L., POUTIAINEN, E. \& KOSKELA, V-H. 1978. Untreated and formaldehyde trated skimmilk powder as a protein supplement for dairy cows. J. Scient. Agric. Soc. Finl. 50: 155-165.

WALDERN, D. E. 1973. Rapeseed meal versus soybean meal as the only protein supplement for lactating cows fed a corn silage roughage ration. Can. J. Anim. Sci. 53: 107-112.

Ms received May 24, 1982 


\title{
Rypsirouhe korkeatuottoisen lypsylehmän valkuaisen lähteenä säilörehu- ja heinäruokinnalla
}

\author{
Liisa Syrjälä-Qvist, Mikko Tuori ja Jouko Setälä \\ Helsingin yliopiston kotieläintieteen laitos, 00710 Helsinki 71
}

Tutkimuksen tarkoituksena oli verrata rypsirouhetta ja rypsirouhetta + ureaa soijarouheeseen runsastuottoisen lypsylehmän valkuaisen lähteenä. Maidontuotantoon tarvittavasta valkuaisesta korvattiin eri koeryhmissä noin 25 \% mainituilla valkuaisväkirehuilla. Rypsirouhe oli pääasiassa Span-lajiketta. Perusrehuina olivat nurmisäilörehu, heinä ja ohra-kaura-melassileike-kivennäisseos.

Kokeessa oli yhteensä 24 lehmää, joiden ruokinta oli ravinnontarpeen mukainen ja yksilöllinen. Koe kesti 16 viikkoa, mistä ajasta vertailukauden osuus oli 12 viikkoa.

Rypsirouhe osoittautui lähes soijarouheen veroiseksi valkuaislähteeksi. Rehun syönnissä ja hyväksikäytössä, maitomäärissä ja maidon koostumuksessa sekä elopainon muutoksissa ei ollut merkittäviä eroja $(\mathrm{P}>0.05)$ eri ryhmien välillä. Mainittua rypsirouhetta voidaan näin ollen suositella käytettäväksi ainakin 13-14\% lypsylehmän väkirehuseoksessa ja päivittäiset rypsirouhemäärät voivat haitatta nousta 1.2 kiloon. Säilörehun valkuaisen korvaaminen rypsirouheella tai soijarouheella näytti parantavan koko rehuannoksen valkuaisen hyväksikäyttöä maidon tuotannossa. 